\title{
Late Holocene Landscape Evolution and Land- Use Expansion in Tutuila, American Samoa
}

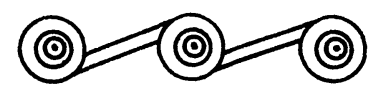

FREDERIC B. PEARL

THIRTY-FIVE YEARS AGO, A STUDY OF OXYGEN-ISOTOPE RATIOS from a speleothem (cave formation) in New Zealand demonstrated that a rapid temperature drop occurred in southern Polynesia in the fourteenth century. Wilson et al. (1979) proposed that the violent climatic conditions accompanying this temperature drop would not only have resulted in increased latitudinal temperature variants but would also have had catastrophic effects on agriculture. At the same time, the more violent climate would have made long-distance voyages inherently more dangerous.

More recently, Bridgeman (1983), based on an extensive review of previously published climatological data, proposed that climatic change may have contributed to a general collapse in Polynesian migrations after A.D. 1350. These studies have received renewed discussion since 1995 when Nunn (1995, 1998, 1999, 2000) published sea level data synchronized to climate change, proposing his own theory that changing climatic conditions had a profound regional effect on Polynesian culture.

A better understanding of climate-induced landscape change is necessary in order to better model human response to dynamic ecosystems. Climate change may result in systematic environmental adjustments in an alluvial catchment. Because archaeological sites are found within Holocene-age sediments, it is necessary to understand the late Quaternary history of the region in order to understand prehistoric settlement patterns and the completeness of the archaeological record.

In order to determine the extent to which changes in the late Holocene geological record correlate with climate and ecological changes over the same period, geoarchaeological explorations were undertaken in A'asu on the remote northern shores of Tutuila Island, American Samoa (Fig. 1). ${ }^{1}$ As the geochronology became known, it was apparent that the sedimentary record had been highly irregular in the late Holocene, particularly after A.D. 1300. Explaining the causes of that dynamism became the focus of research over the next several years. In this article, geoarchaeological data from A'asu are compared with similar data from coastal settings (Ayres and Eisler 1987; Clark and Michlovic 1996; Hunt and Kirch 1997) and combined with recent research on the establishment of mountain set-

Frederic B. Pearl is with the Maritime Studies Program, Texas A\&M University at Galveston. 


\section{Tutuila Island}

\section{American Samoa}

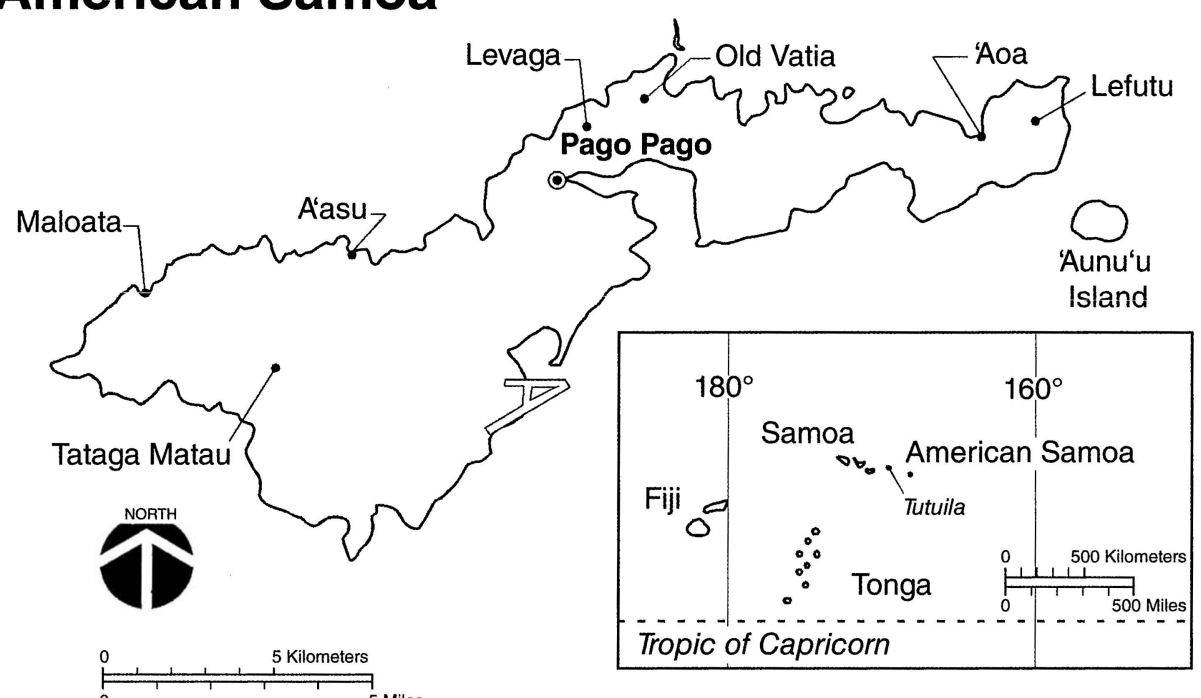

Fig. 1. Map of Tutuila Island showing project area and other archaeological sites mentioned in the text. Regional inset.

tlements (Pearl 2004) to show that changes in climate, settlement patterns, and landscape evolution converged, beginning in the fourteenth century A.D., a time when social complexity was on the rise in Samoa.

\section{PROJECT SETTING}

The lush valley of A'asu is situated on the north coast of western Tutuila, with numerous inhabitable valleys undisturbed by roads and contemporary settlements, standing in stark contrast to other more populated and developed areas of Tutuila. The valley floor extends about $0.5 \mathrm{~km}$ inland and comprises about $0.1 \mathrm{~km}^{2}$ of mostly gently sloping terrain. A considerable freshwater stream, derived from runoff and several springs high in the mountains, dissects the valley floor. The springs provide a perennial source of fresh water and likely made this valley particularly attractive to prehistoric inhabitants.

A'asu provided a fortuitous starting point for geoarchaeological study because its constricted valley opening yet fairly large catchment cause it to act like a "graduated cylinder," accentuating periods of erosion and stability in the stratigraphic record. The stratigraphy of A'asu Valley is seen as a component piece in the larger picture of late Holocene landscape evolution in eastern Samoa.

The valley is formed of alluvial sediments transported along A'asu Stream and its tributaries and colluvium eroded from the steep-sided valley walls. Slopeeroded colluvium has created thick deposits along the valley floors and margins that interfinger with alluvium deposited by the stream. Along the coastal plain, 
sediments have been reworked by wave action, storms, and fluctuations of sea level.

A village at the mouth of the valley was encountered in 1787 when the French explorer La Pérouse made landfall on Tutuila. At their meeting in 1787, Samoans and French explorers clashed at A'asu, resulting in the deaths of an undetermined number of Samoans, the French expedition's second in command (de Langle), and 11 other members of the landing party (de Langle 1954; Dunmore 1994:397-411; Milet-Mureau 1797). Today there are no permanent inhabitants of the village, but it is a popular site for seasonal fishing activities. Taro and other cultigens are farmed nearby.

Emerged reef fragments visible from A'asu and at more than 20 other locations around the island indicate that relative sea levels are lower at present than earlier in the Holocene. Stearns (1944) was the first to consider that these were evidence for a higher sea stand, but their late Holocene dates were not known until recently. Nunn (1998) dated six reef fragments ranging from 0.75 to $2.11 \mathrm{~m}$ above mean sea level, each of which dated to the last 1000 years.

Similar data have been obtained in western Samoa, where raised beach rock indicates a mid-Holocene highstand of $0.8-2.3 \mathrm{~m}$ at $1200-1850 \pm 70$ years B.P. (Grant-Taylor and Rafter 1962; Rodda 1988; Sugimora et al. 1988). Independently, Dickinson (2001) reports the differential elevation between modern and emergent wavecut coastal benches offshore of Tutuila (on the islet of Aunu'u) at $1.8 \pm .01 \mathrm{~m}$, a figure very close to the calculated theoretical value of $1.9 \mathrm{~m}$ (Mitrovica and Peltier 1991). Furthermore, coastal progradation on 'Upolu since 700-1000 years B.P. has been attributed to systemic adjustments caused by lowering sea levels (Goodwin and Grossman 2003). This interpretation underscores the need for additional studies on the impact of climate and sea level change on landscape evolution in Samoa. Though some islands in the Samoan chain are experiencing subsidence or upflexure due to volcanic activity, the islands of Tutuila and Aunu'u are not thought to have experienced any significant vertical change (Dickinson and Green 1998).

Eustatic shoreline movements on Tutuila are key to interpreting the geomorphic changes at A'asu. Comparing an elevated beach rock geochronology with data from 18 other tectonically stable sites in the Pacific, Nunn (1998) summarized eustatic shoreline movements on Tutuila during the last millennium as follows: (a) a sea level rise, coincident with a period of warming known as the Little Climatic Optimum, between 1050 and 690 B.P.; (b) a sea level drop during the Little Ice Age, between 575 and 150 B.P.; and (c) a period of recent warming during the last 150 years. The transition between Little Climatic Optimum and Little Ice Age, which peaked between 690 and 575 B.P., was marked by rapid cooling and possibly a concurrent increase in rainfall (Bridgeman 1983; Nunn 2000).

\section{RESEARCH METHODS}

A study of the geochronology of A'asu was conducted simultaneously with archaeological investigations; consequently, geological profiles discussed herein are those of the archaeological excavation units (sondages). The work was completed in two eight-week field seasons in the months of May and June of 2001 and 
2002. The research was initiated by the author as the first step in a multiyear research plan to better understand the late precontact archaeology of Samoa. The fieldwork was conducted by the author, several graduate and undergraduate students, and professional excavators. Because the final report of the archaeological investigations is still in preparation, the general methods and procedures are summarized below.

The archaeological plan called for multiple $1 \times 1 \mathrm{~m}$ sondages, sometimes contiguously grouped into block's, to be located across the landscape. Fifteen such sondages were tested in this manner and labeled blocks A through E (Fig. 2). Of those blocks, this study will focus only on blocks $A$ and $D$, which provided deep

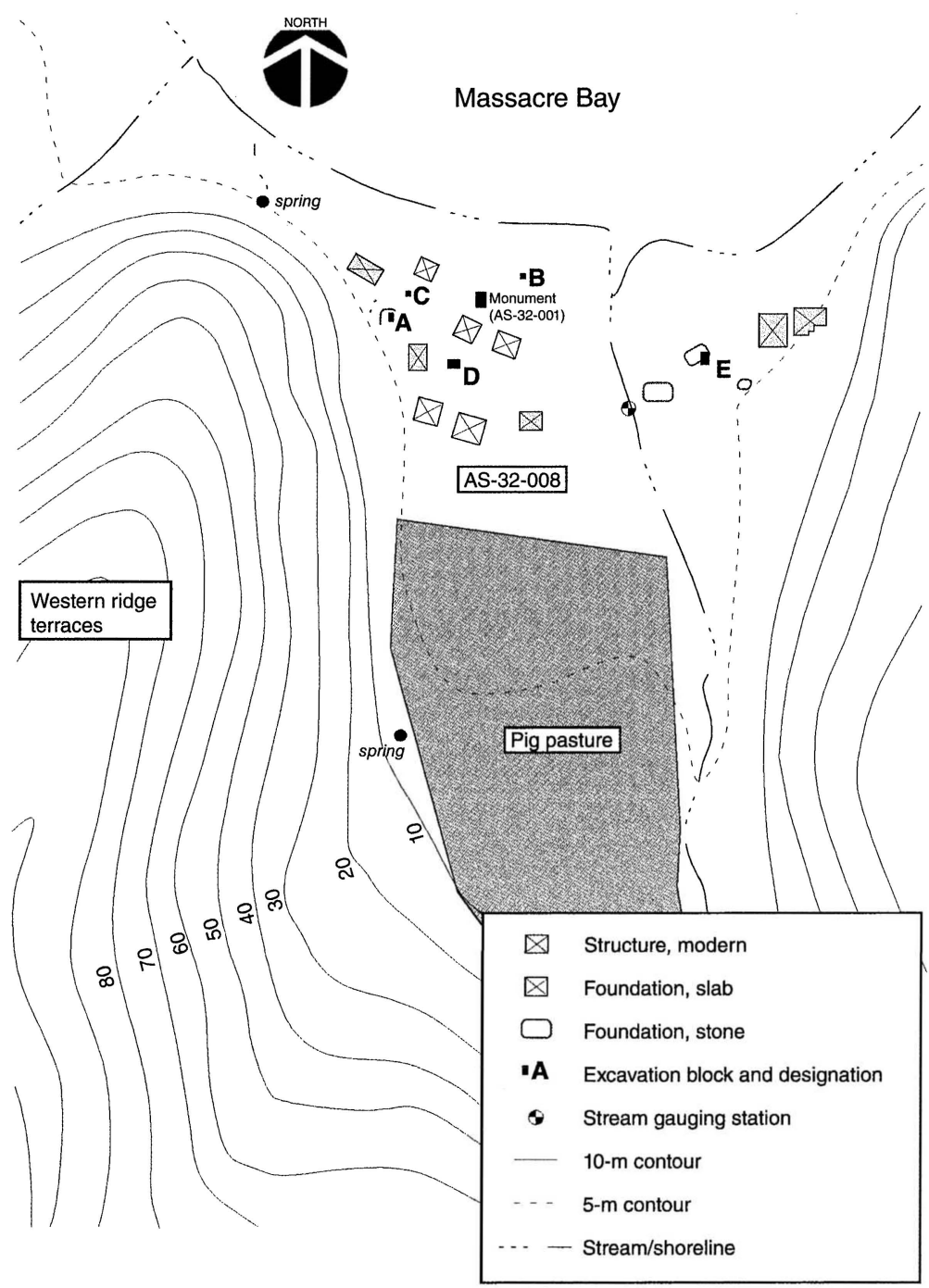

Fig. 2. Map of A'asu (AS-32-008) showing modern structural features and the locations of excavation blocks (A-E). 1883 memorial to massacre also indicated (AS-32-001). 
exposures of alluvium exhibiting stratification and abundant charcoal for dating (the remaining blocks focused principally on surface deposits).

Block A was situated inland near the valley margin in a setting that was expected to have abundant colluvium, while block D was situated on the modern floodplain of A'asu Stream. Both of the blocks were located in depositional settings, but it was anticipated that block A would reveal higher sedimentation rates due to its location at the toe of a steep valley wall. Ultimately, block A was expanded to include two adjacent sondages, reaching a maximum depth of $2.0 \mathrm{~m}$. Block D was expanded to include five contiguous sondages, reaching a maximum depth of $1.3 \mathrm{~m}$.

Excavations proceeded in arbitrary $10-\mathrm{cm}$ levels or by natural stratigraphy when change occurred within these. All sediments from block A (excavated in year 1 ) were screened through $1 / 8^{\prime \prime}$ mesh, while $1 / 4^{\prime \prime}$ mesh was used in block $\mathrm{D}$ (excavated in year 2 ). The change was made between seasons after careful consideration of the materials being recovered and time available to us in the second season. Water screening was employed at block A when the clay fraction exceeded about 30 percent. Artifacts were point-plotted before removal when possible. A stratigraphic cross-section was made for each completed excavation block, which was then photographed and backfilled.

Sediment samples were routinely taken at least once every $10 \mathrm{~cm}$. Charcoal was so ubiquitous that no fewer than four samples were taken every $10 \mathrm{~cm}$. The process of washing, sorting, cataloging, and analyzing artifacts began in the field and was completed in the archaeology laboratory at Texas A\&M-Galveston. Soils and sediments exposed in sections were described using standard procedures and terminology outlined by Soil Survey Staff (2003). Major lithostratigraphic distinctions are made by grouping substrata into major strata, numbered consecutively I, II, and III. Subtle changes within these strata are given an alphanumeric designation (e.g., Ia or Ib).

Radiocarbon ages are reported in Table 1 and discussed in the following section. For interpretive purposes, the conventional radiocarbon age was calibrated with the OxCal 3.10 radiocarbon calibration software (Bronk Ramsey 2001, 2005) using the INTCAL04 atmospheric carbon curve for calibration (Reimer et al. 2004).

\section{STRATIGRAPHIC SEQUENCE}

Block $A$

The two sondages comprising block A were situated directly on a stone-lined house platform. Such platforms were the predominant foundation type in ethnohistoric accounts of Samoa, providing foundations for dwellings, ceremonial guest houses, cooking houses, and even churches and other buildings. This one, like most others, is covered in a pavement of gravels (' ${ }^{\prime}$ il 'ili) and bordered by one course of basalt stones (lautasi) (terms from Hiroa 1930:66-67).

Most of the sediments encountered were terrigenous. However, some sands, corals, and shells were intermixed with the alluvium and colluvium, especially in the uppermost strata. Soil horizons (pedostratigraphy) and lithological discontinuities (lithostratigraphy) were both noted. Based on their lithology and deposi- 
Table i. Radiocarbon Ages from A'asu (AS-32-0o8)

\begin{tabular}{|c|c|c|c|c|c|c|}
\hline \multirow[b]{2}{*}{ LAB NO. ${ }^{a}$} & \multirow[b]{2}{*}{ LEVEL } & \multirow[b]{2}{*}{ DEPTH } & \multirow{2}{*}{$\begin{array}{l}\delta^{13} \mathrm{C} \\
(\%)\end{array}$} & \multirow{2}{*}{$\begin{array}{l}{ }^{14} \mathrm{C} \\
\mathrm{AGE}\end{array}$} & \multicolumn{2}{|c|}{ CALIBRATED RESULTS ${ }^{b}$} \\
\hline & & & & & I-SIGMA & 2-SIGMA \\
\hline A-12406 & A:Ie & 55 & -26.8 & $0 \pm 110$ & $\begin{array}{l}\text { A.D. } 1690-1730(16.4 \%) \\
\text { A.D. } 1800-1930(48.6 \%) \\
\text { A.D. } 1950 \ldots(3.2 \%)\end{array}$ & A.D. $1660 \ldots(95.4 \%)$ \\
\hline AA-51255 & A:IIb & $80-90$ & -25.5 & $355 \pm 35$ & $\begin{array}{l}\text { A.D. } 1470-1530(33.3 \%) \\
\text { A.D. } 1570-1630(34.9 \%)\end{array}$ & A.D. $1450-1640(95.4 \%)$ \\
\hline AA-51257 & A:IIIb & 145 & -26.5 & $625 \pm 35$ & $\begin{array}{l}\text { A.D. } 1295-1325(25.3 \%) \\
\text { A.D. } 1345-1395(42.9 \%)\end{array}$ & A.D. $1280-1400(95.4 \%)$ \\
\hline $\begin{array}{l}\text { Beta- } \\
171844\end{array}$ & A:IIIb & $141-152$ & -23.4 & $630 \pm 40$ & $\begin{array}{l}\text { A.D. } 1290-1320(26.3 \%) \\
\text { A.D. } 1345-1395(41.9 \%)\end{array}$ & A.D. $1280-1410(95.4 \%)$ \\
\hline AA-51256 & A:IIIb & $161-171$ & -27.1 & $635 \pm 35$ & $\begin{array}{l}\text { A.D. } 1290-1320(27.3 \%) \\
\text { A.D. } 1350-1390(40.9 \%)\end{array}$ & A.D. $1280-1400(95.4 \%)$ \\
\hline $\begin{array}{l}\text { Beta- } \\
\quad 171845\end{array}$ & A:IIIb & $171-182$ & -28.6 & $710 \pm 40$ & $\begin{array}{l}\text { A.D. } 1260-1300(59.6 \%) \\
\text { A.D. } 1360-1380(8.6 \%)\end{array}$ & $\begin{array}{l}\text { A.D. } 1220-1320(77.2 \%) \\
\text { A.D. } 1350-1390(18.2 \%)\end{array}$ \\
\hline Pra-9185 & D:IIa & $50-70$ & -24.8 & $320 \pm 45$ & A.D. $1510-1650(68.2 \%)$ & A.D. $1460-1660(95.4 \%)$ \\
\hline Pra-9183 & D:IIb & $80-90$ & -25.1 & $340 \pm 50$ & $\begin{array}{l}\text { A.D. } 1480-1530(23.4 \%) \\
\text { A.D. } 1550-1640(44.8 \%)\end{array}$ & A.D. $1450-1650(95.4 \%)$ \\
\hline $\begin{array}{l}\text { Beta- } \\
180372\end{array}$ & D:IIIa & 105 & -25.8 & $650 \pm 50$ & $\begin{array}{l}\text { A.D. } 1280-1320(31.8 \%) \\
\text { A.D. } 1350-1390(36.4 \%)\end{array}$ & A.D. $1270-1410(95.4 \%)$ \\
\hline
\end{tabular}

Notes:

a. Standard radiocarbon ages were determined for charcoal by the University of Arizona, Laboratory of Isotope Geochemistry (A), and the Quaternary Research Dating Unit, South Africa (Pra). AMS ages were conducted by the University of Arizona National Science Foundation Arizona AMS Facility (AA) or by Beta Analytic (Beta).

b. Calibrations were by OxCal (Bronk Ramsey 2001, 2005) using standard atmospheric data from INTCAL04 (Reimer et al. 2004). 
Table 2. Technical Description of Sedimentary Morphology FOR BlOCK A (UNIT 2)

\begin{tabular}{|c|c|c|}
\hline LAYER & AVG. DEPTH (CM.) & DESCRIPTION \\
\hline Ia & $0-13$ & $\begin{array}{l}\text { Very dark grayish-brown }(10 \mathrm{YR} 3 / 2) \text { massive pebbly clay loam up } \\
\text { and occasional cobbles; structureless; pebbles range from white } \\
\text { (coral) to black/blue basalt; abrupt irregular boundary. }\end{array}$ \\
\hline $\mathrm{Ib}$ & $12-15$ & $\begin{array}{l}\text { White }(2.5 \mathrm{Y} 8 / 1) \text { fine to medium, well-sorted beach sand (with } \\
\text { gray and black flecks throughout); structureless; less that } 5 \% \\
\text { pebbles; pinches out in north and east wall (lens); abrupt } \\
\text { irregular boundary. }\end{array}$ \\
\hline Ic & $15-30$ & $\begin{array}{l}\text { Bleached white }(\mathrm{N} 8 / \text { ) coral pebbles with some sand matrix } \\
\text { (possibly from layer Ib); dark bluish grey basaltic pebbles less } \\
\text { than 20\%; structureless; abrupt smooth boundary. }\end{array}$ \\
\hline Id & $30-37$ & $\begin{array}{l}\text { Very dark grayish brown (10YR } 3 / 2) \text { pebbly sandy clay; pebbles } \\
\text { and gravels make up to } 30 \% \text { of matrix, including some fire- } \\
\text { cracked rock; fine subangular blocky structure; some charcoal } \\
\text { and rootlets; abrupt irregular boundary. }\end{array}$ \\
\hline $\mathrm{Ie}$ & $37-49$ & $\begin{array}{l}\text { Heterogeneous, poorly sorted clastic layer, dominated by large } \\
\text { cobbles and fire-cracked rock, ranging up to } 15 \mathrm{~cm} \text {.; abundant } \\
\text { pebbles and fire cracked gravel size pieces; medium subangular } \\
\text { blocky structure; rock types include pumice, basalt, and coral } \\
\text { cobbles; charcoal infrequent; abrupt irregular boundary. }\end{array}$ \\
\hline IIa & $49-65$ & $\begin{array}{l}\text { Very dark grayish brown (10YR3/2) sandy/pebbly clay loam (up } \\
\text { to } 25 \% \text { pebbles and gravels); medium subangular blocky } \\
\text { structure; abundant marine shells (mixed species, but intact } \\
\text { Turbo spp. frequent) as well as some bone and charcoal; shells } \\
\text { become less frequent with depth; clear smooth boundary. }\end{array}$ \\
\hline $\mathrm{IIb}$ & $65-88$ & $\begin{array}{l}\text { Very dark grayish brown (10YR } 3 / 2) \text { sandy/pebbly clay loam (up } \\
\text { to } 25 \% \text { pebbles and gravels); medium subangular blocky } \\
\text { structure; infrequent marine shells (mixed species) as well as } \\
\text { some bone and charcoal; clear irregular boundary. }\end{array}$ \\
\hline IIIa & $88-150$ & $\begin{array}{l}\text { Brown (7.5YR 4/4) sandy clay loam; dispersed charcoal } \\
\text { throughout; some fire-cracked cobbles; medium angular blocky } \\
\text { structure; hearth feature at the contact between this and } \\
\text { underlying layer; gradual smooth boundary. }\end{array}$ \\
\hline IIIb & $150-200$ & $\begin{array}{l}\text { Dark brown (7.5YR3/4) sandy clay; dispersed charcoal } \\
\text { throughout; some fire-cracked crocks; coarse angular blocky } \\
\text { structure; one large boulder; unit terminated. }\end{array}$ \\
\hline
\end{tabular}

tional features, ten divisions were recognized within the three major strata (Table 2; Fig. 3).

Strata Ia-Ie - Strata Ia through Ie reflect the construction sequence of the house platform, with Ie consisting of loose coral and basalt cobbles representing the first stage of construction. The contact between strata Ie and IIa beneath is abrupt and irregular, indicating that some erosion or intentional clearing may have preceded the deposition of Ie.

A conventional radiocarbon determination of $100 \pm 1.4 \mathrm{pMC}(\mathrm{A}-12406)$ was obtained on charcoal from the bottom of stratum Ie. Taken at face value, 100 percent modern carbon would indicate a date of about A.D. 1950. However, the lower limit (2-sigma) calculates to the interval A.D. 1660 -present. The upper 


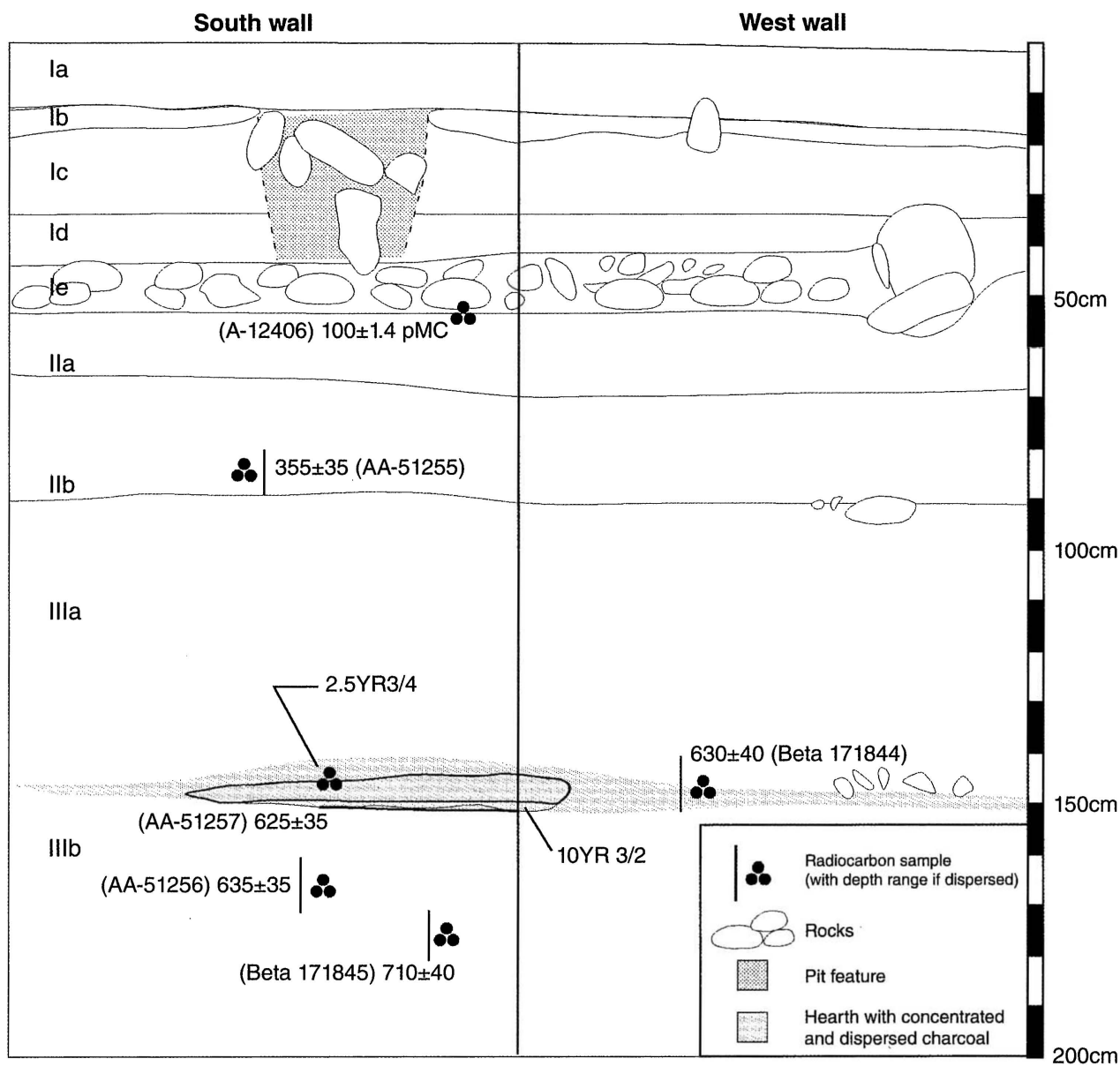

Fig. 3. Representative profile of block A, unit 2, showing the elevations of radiocarbon samples. Calibrated radiocarbon ages shown (B.P.).

limit falls in the mid-1950s if all the carbon was fixed in a single year. Better precision is not possible in this interval of time because of high atmospheric carbon variations (Stuiver and Pearson 1993). The corrected age for this sample is equivalent to $0 \pm 110$ B.P. Most likely the structure dates to A.D. 1800-1930, although an earlier date cannot be ruled out (see Table 1).

Strata IIa-IIb - Stratum II consists predominately of clay loams, but a significant fraction of pebbles, gravels, and shells make the group quite heterogeneous. Stratum IIa is made of very dark grayish-brown sandy clay loam, with as much as 25 percent of the matrix pebble and larger-sized clasts. Most pebbles are subrounded, indicating not only their colluvial origin but that they have rolled some distance prior to deposition. There are abundant marine shells throughout these sediments, many exhibiting burning, and high densities of other cultural artifacts, though their numbers decrease with depth. Abundant charcoal and bone were also recovered at the contact with the overlying stratum. 
Stratum IIb transitions smoothly over a $10-\mathrm{cm}$ boundary. This is a pedogenic distinction; that is, the boundary was formed through natural soil-forming processes. It is identical in color and texture to IIa and is distinguished principally by soil structure and the rapid reduction in the number of marine shells, though they still constitute a small fraction of the horizon.

A radiocarbon age of $355 \pm 35$ B.P. (AA-51255) indicates that deposition of stratum II was under way in the fifteenth century (see Table 1). It is separated from stratum III by an abrupt irregular boundary, an indication that erosion occurred between the two.

Strata IIIa-IIIb - Stratum III consists of fairly homogenous sandy clays, with clay content slightly increasing with depth. The principle differentiation between subhorizons $\mathrm{a}$ and $\mathrm{b}$ is that the latter is slightly darker (dark brown vs. brown) and has higher clay content (sandy clay vs. sandy clay loam). The changes in color and texture are related and occur gradually with depth. Stratum III is generally more fine grained than the overlying strata, suggesting, in the absence of any evidence for pedogenically altered clays, that water transport played a greater role in depositing the sediments. However, occasional angular rocks and a large boulder encountered at the base of block A reveal that much of the deposition is still colluvial (from the slopes) rather than fluvial (from the flooding of A'asu Stream). Stratum IIIb is the deepest and oldest encountered, and there is abundant charcoal dispersed in this layer.

Four radiocarbon ages were determined on charcoal from stratum III. Two samples were taken from the burned hearth mentioned above. A third and fourth sample were taken from dispersed charcoal beneath the hearth area elsewhere in the layer. The samples were separated by a distance of no more than $20 \mathrm{~cm}$. The two samples from the hearth returned calibrated radiocarbon ages of $625 \pm 35$ B.P. (AA-51257) and $630 \pm 40$ B.P. (BETA-171844). The samples beneath the hearth returned calibrated radiocarbon ages of $635 \pm 35$ B.P. (AA51256) and $710 \pm 40$ B.P. (BETA-171845).

\section{Block D}

The five sondages comprising block D were situated on the alluvial plain (see Fig. 2). At first glance it appears to be an area devoid of architectural features, and initially the first sondage was placed there to establish the underlying stratigraphy of the alluvial plain. However, archaeological discoveries necessitated expanding the block to a full $5 \mathrm{~m}^{2}$. Cultural materials were encountered in each stratum, including an adult human burial in IIIa. Based on their lithology and depositional features, seven divisions were recognized within the three major strata (Fig. 4; Table 3). Like block A, most of the sediments encountered were terrigenous. However, some marine sands, corals, and shells were intermixed with the alluvium and colluvium, especially in the uppermost strata, such as Ia below.

Stratum $I a-I c-$ A $5-\mathrm{cm}$ veneer of sand coats the surface. This sand, comprising stratum Ia, likely resulted from hurricanes that blasted this coastline in the 1990s. Former residents report that the village was leveled at that time and significant volumes of seawater flooded the low-lying parts of the village.

Stratum Ia abruptly overlies stratum Ib, a very dark grayish-brown sandy loam. 


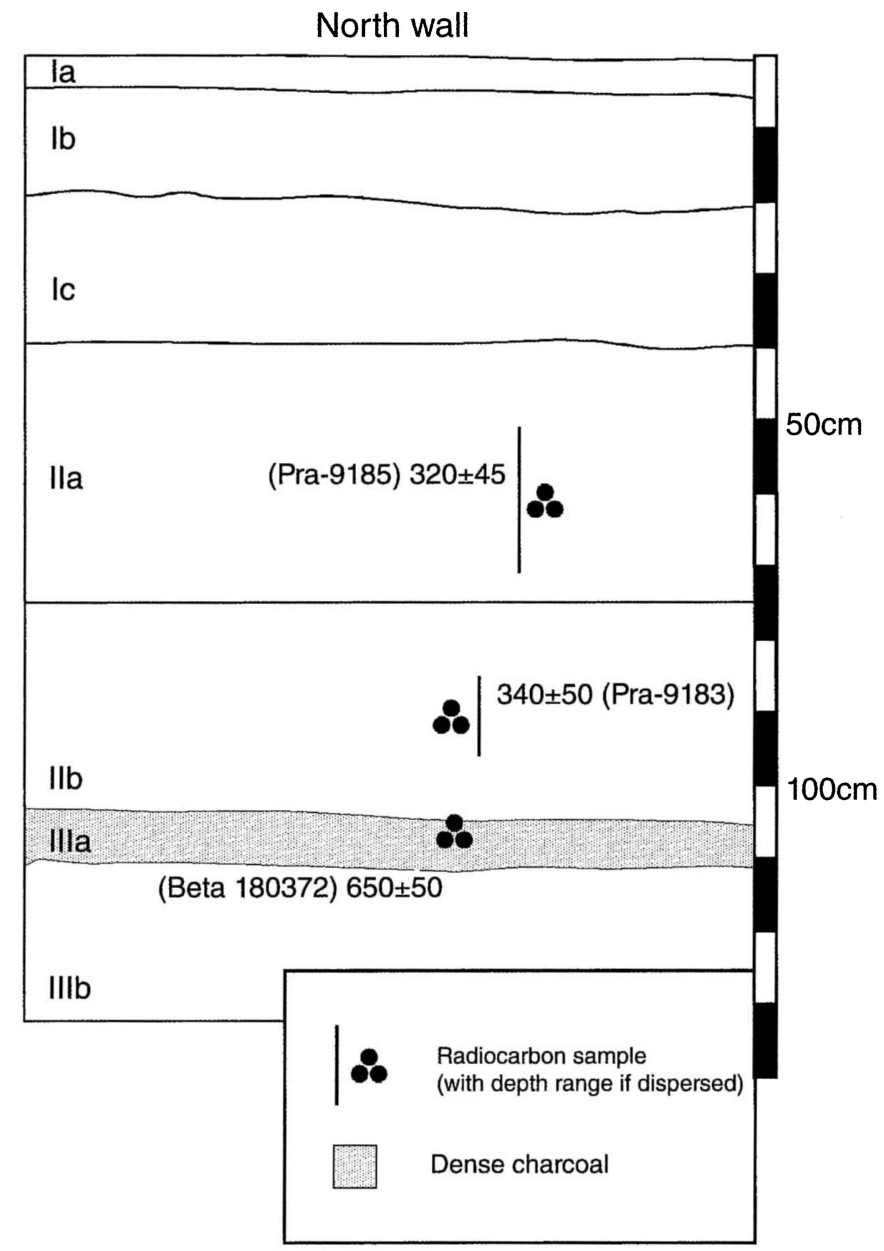

Fig. 4. Representative profile of block $\mathrm{D}$, unit 5, also showing locations of radiocarbon samples. Calibrated radiocarbon ages shown (B.P.).

Pebbles and gravels make up to 20 percent of the matrix, which also contains small amounts of fire-cracked rock and charcoal.

Stratum Ic represents a single anthropogenic horizon. Its coral cobbles and matrix of gravelly, sandy clay loam was initially encountered in the floor of some sondages. As the excavation area was laterally expanded, it became clear that this clast-supported matrix was bounded on the south by a line of basalt boulders. These were $20-30 \mathrm{~cm}$ across and are consistent with those seen bordering domestic areas in ethnohistoric contexts. The floor was punctuated by a cobble-lined pit feature extending into the underlying strata.

Strata IIa-IIb - Directly beneath the contact of stratum I, a soil-enriched, very dark grayish-brown sandy to gravelly clay loam (up to 20 percent pebbles and gravels) was encountered (stratum IIa). Many marine shells were also encountered, as well as some bone, charcoal, and other cultural material. This stratum, 
Table 3. Technical Description of Sedimentary Morphology FOR BLOCK D (UNIT 5)

\begin{tabular}{|c|c|c|}
\hline LAYER & AVG. DEPTH (CM.) & DESCRIPTION \\
\hline Ia & $0-5$ & $\begin{array}{l}\text { White }(2.5 \mathrm{Y} 8 / 1) \text { fine to medium, well-sorted beach sand (with } \\
\text { gray and black flecks. }\end{array}$ \\
\hline $\mathrm{Ib}$ & $5-22$ & $\begin{array}{l}\text { Very dark grayish-brown (10YR } 3 / 2) \text { pebbly sandy loam; pebbles } \\
\text { and gravels make up to } 20 \% \text { of matrix, including some fire- } \\
\text { cracked rock, charcoal and rootlets; structureless; abrupt } \\
\text { irregular boundary. }\end{array}$ \\
\hline Ic & $22-39$ & $\begin{array}{l}\text { Basalt boulders and slabs of coral (up to } 32 \mathrm{~kg} \text { ) predominate; } \\
\text { matrix is dark grayish brown (10YR } 4 / 2 \text { ) pebbly sandy clay } \\
\text { loam; pebbles and gravels make up to } 20 \% \text { of matrix, including } \\
\text { some fire-cracked rock, charcoal and rootlets; structureless; } \\
\text { abrupt irregular boundary. }\end{array}$ \\
\hline IIa & $39-48$ & $\begin{array}{l}\text { Very dark grayish-brown (10YR3/2) sandy/pebbly clay loam (up } \\
\text { to } 20 \% \text { pebbles and gravels); fine subangular blocky structure; } \\
\text { abundant marine shells (mixed species) as well as some bone } \\
\text { and charcoal; shells become less frequent with depth; gradual } \\
\text { smooth boundary. }\end{array}$ \\
\hline Iİb & $48-106$ & $\begin{array}{l}\text { Dark grayish-brown (10YR } 4 / 2) \text { sandy/pebbly clay loam (up to } \\
10 \% \text { pebbles and gravels); medium subangular blocky structure; } \\
\text { few marine shells (mixed species) as well as some bone and } \\
\text { charcoal; shells become less frequent with depth; clear smooth } \\
\text { boundary. }\end{array}$ \\
\hline IIIa & $106-118$ & $\begin{array}{l}\text { Very dark gray ( } 7.5 \mathrm{YR} 3 / 1) \text { to black }(7.5 \mathrm{YR} 2.5 / 1) \text { sandy clay } \\
\text { loam; infrequent marine shells (mixed species) as well as some } \\
\text { bone; medium angular blocky structure; charcoal abundant; } \\
\text { clear smooth boundary. }\end{array}$ \\
\hline IIIb & $118-131$ & $\begin{array}{l}\text { Brown (7.5YR 4/2) sandy clay; dispersed charcoal throughout; few } \\
\text { fire-cracked and normal cobbles; medium angular blocky } \\
\text { structure; sediments saturated; unit terminated. }\end{array}$ \\
\hline
\end{tabular}

distinctly darker than the overlying layer, could be seen clearly following the outline of pit features in adjacent sondages (not shown in Fig. 4). Charcoal from the base of IIa provided a radiocarbon age of $320 \pm 35$ B.P. (PRA-9185).

Stratum IIb transitions smoothly over a $10-\mathrm{cm}$ boundary. It is distinguished from IIIa by a slightly lighter value (dark grayish-brown), as well as by decreasing gravels, shells, and cultural finds. It terminates abruptly and lacks any soil development. Charcoal from the base of this stratum provided a radiocarbon age of $340 \pm 50$ в.P. (PRA-9183).

Strata IIIa-IIIb - Stratum III consists of homogenous sandy clays, with clay content slightly increasing with depth. It is lithologically distinctive from stratum II; the abrupt planar boundary between them represents an erosional disconformity. The principle differentiation between IIIa and IIIb is that the former is strongly discolored by abundant charcoal. The entire horizon can be characterized as an ashy mass of poorly sorted, decomposing charcoal fragments in sandy clay, with some lithics and faunal remains. It would not be appropriate to refer to the layer as a lens because its lateral extent remains unknown. Further, there was no evidence of any depression or depositional cavity that might have bounded the layer. 
The lower boundary was clear but not abrupt, with a transition to IIIb visible over about $5 \mathrm{~cm}$. Charcoal content in the underlying stratum was dramatically lower.

Stratum III is generally more fine grained than the overlying strata, suggesting that fluvial transport played a greater role in depositing the sediments. Stratum IIIb is the deepest and oldest of the sedimentary units. It contained abundant cultural material as well, including an adult burial, a fishing weight (not associated with the burial), and other cultural materials.

A single radiocarbon age was determined on charcoal from stratum III. A large sample of concentrated charcoal from IIIa returned an AMS age of $650 \pm 50$ B.P. (BETA-180372).

\section{INTERPRETED GEOCHRONOLOGY OF A'ASU}

Correlation of the stratigraphy between blocks A and D is based on the lithology and soil morphology, and major strata given the same designation (i.e., I, II, or III) are interpreted as being part of the same depositional layer.

Atmospheric radiocarbon fluctuations between A.D. 1325 and 1375 make calibration of dates in the fourteenth century problematic. Conventional radiocarbon ages between about 500 and 700 B.P. have a bimodal probability distribution when calibrated. Furthermore, many of the dates that I- cite were calibrated using different calibration curves than are now available. Consequently, for comparative purposes I will emphasize the ages in radiocarbon years (B.P.), which are consistently reported in the papers cited and are independent of calibration curves.

Figure 5 shows the calibrated probability distributions for the nine radiocarbon determinations in Table 1 . These dates essentially cluster into three groups. A chisquare of the five dates from stratum III reveals that they are statistically the same at the 95 percent confidence interval $\left(648 \pm 17 ; \mathrm{df}=4 ; \mathrm{T}=3.2 ; \chi^{2}(.05)=9.5\right)$. Similarly, a chi-square of the three dates from stratum II reveals that they are statistically identical at the 95 percent confidence interval $(341 \pm 24$; $\mathrm{df}=2$; $\left.\mathrm{T}=0.4 ; \chi^{2}(.05)=6.0\right)$. This gives a high degree of confidence that the gap between stratum II and III is real and suggests that the vacuity represents about 300 years.

The oldest radiocarbon date from A'asu is $710 \pm 40$ years B.P., obtained from charcoal in stratum IIIb in block A. A small number of lithics, including an adze fragment, were recovered beneath this charcoal sample. Utilization of A'asu Valley therefore began prior to $710 \pm 40$ B.P. During the Little Climatic Optimum ( $\sim 1050$ B.P. to $\sim 690$ B.P.), the predominance of well-sorted, fine-grained alluvium in the valley suggests that fluvial processes predominated. The dispersed charcoal in the deepest sondages probably indicates that swidden agriculture played an important role in subsistence patterns at that time, though fire from natural causes cannot be ruled out. It should be noted, however, that while human use of fire for agricultural purposes in moist tropical environments is very common, large natural fires are very uncommon.

Around $650 \pm 50$ B.P., the valley floor was blanketed by charcoal, at least locally, after which the surface was truncated by erosion. The precise timing of this erosional event is unknown because the sediments related to it have been flushed out of the valley. The direct source of the charcoal is also undetermined, but 


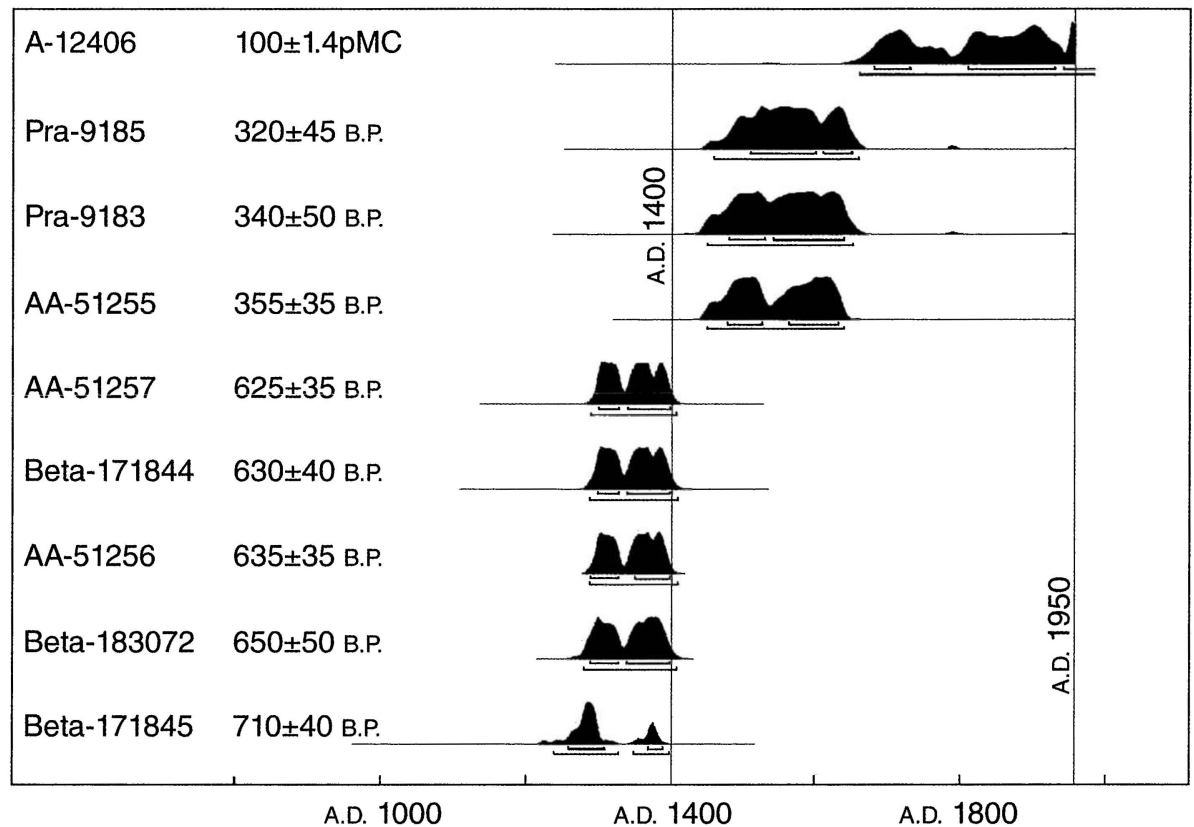

Fig. 5. Probability distributions of radiocarbon calibrations using atmospheric data from Reimer et al. (2004); results from OxCal Version 3.10 by Bronk Ramsey (2005).

erosion across the valley floor may be due to decreased vegetation cover. A date on the overlying stratum of $355 \pm 55$ B.P. means that the lacuna represented by the erosion includes the transitional period between the Little Climatic Optimum and the Little Ice Age of the Late Holocene ( $\sim 690$ to $\sim 575$ B.P.) and might be directly correlated to it.

Deposition of the stratum II was under way no later than $355 \pm 35$ B.P. On the valley margin, rapid colluvial deposition predominated, with minimal alluvium, while deposition on the valley floor was a mixture of colluvium and alluvium. The increased sediment yield was coincident with the Little Ice Age ( $\sim 575$ B.P. to $\sim 150$ B.P.), when both temperature and sea level were lower than present (Nunn 1995, 1998; Wilson et al. 1979).

A mean rate of sedimentary deposition was calculated by dividing minimum vertical accretion (depth between the bottom of stratum I and the deepest radiocarbon determination in each block) by mean accumulation time (as determined by the radiocarbon intercept). Due to the contribution from the steep valley walls, rates of sedimentary deposition along the valley margins were 62 percent higher than on the valley floor. Along the valley margins, sediments accumulated at a mean rate of $16.34 \mathrm{~cm}$ per century $(116 \mathrm{~cm}$ over 710 years). Of course, because of the lacuna left by erosion, the actual rate of deposition was higher at times. Along the floor of the valley, sediments accumulated at a mean rate of $10.15 \mathrm{~cm}$ per century (66 $\mathrm{cm}$ over 650 years). While perhaps over-generalized, 
these calculations indicate that deposition has been significant over the last 700 years.

Throughout the Holocene, sea level constrained the movement of sediment toward the sea. During the Little Climatic Optimum, the alluvial plain aggraded. Then, as the climate transitioned to the Little Ice Age, A'asu Stream cut into its alluvial plain and its gradient increased as it adjusted to a lower sea level. Sea level rise over the past 150 years or so has begun to stabilize the alluvial plain. In Tutuila and Aunu'u, the drop in sea level after the mid-Holocene highstand exposed more landmass and created conditions for prograding shorelines.

\section{ARCHAEOLOGICAL SUMMARY}

The aceramic site of A'asu has a rich historic and prehistoric archaeological record. So that readers may better understand the archaeological context, a brief summary of the archaeology is provided here.

The modern surface is a palimpsest of recent and ethnohistoric discard. Secondary maintenance has removed most artifacts from major walkways, but discarded materials are found around many of the house foundations and at the periphery of the village. Discards range from wire, glass, and metal "trash" to the occasional polished stone flake or adze fragment. Most of the existing house foundations are cement slabs of recent origin, though there are several traditional stone fale foundations as well.

The archaeology of the uppermost excavation layers (stratum I) is closely related to recent village activities. Modern and historic glass, metals, and plastics were recovered, including such diagnostic objects as nails, buttons, and religious devotional medals (Fig. 6). These artifacts are a clear indication that the site was well connected with long-distance trade networks in historic times. Many of the artifacts are marine related-boat-building nails (copper with roves), shell-motif beads, and shell buttons-attesting to the strong connection that the people of A'asu had with the sea.

The archaeology of stratum II was increasingly prehistoric in character, consisting principally of lithics and faunal remains that declined with depth, an indication of the poor preservation conditions at the site. The lithic artifactual remains, however, showed a bias toward non-adze stone tools. A number of worked flakes, especially unifacial scrapers, were encountered, as well as a small number of adzes. Use-wear indicates that the adzes were usable finished products, but they were not highly polished like many other Samoan adzes. Stratum II contained a limited number of historic artifacts, including a kaolin clay pipe fragment of a style that was common at the end of the eighteenth century.

The exclusively prehistoric archaeology of stratum III was very similar to the archaeology of stratum II. Indeed, as of this publication I am not prepared to say that there was a significant difference in terms of lithic technology, and even fewer faunal remains were present. An oval stone "weight" was recovered that might have been a fishing or net weight (Fig. 6). A burial was also recorded in block D, stratum IIIb. No cultural materials were associated with the burial, which was lying on its right side-facing north, toward the sea-in a flexed position. $^{2}$ 

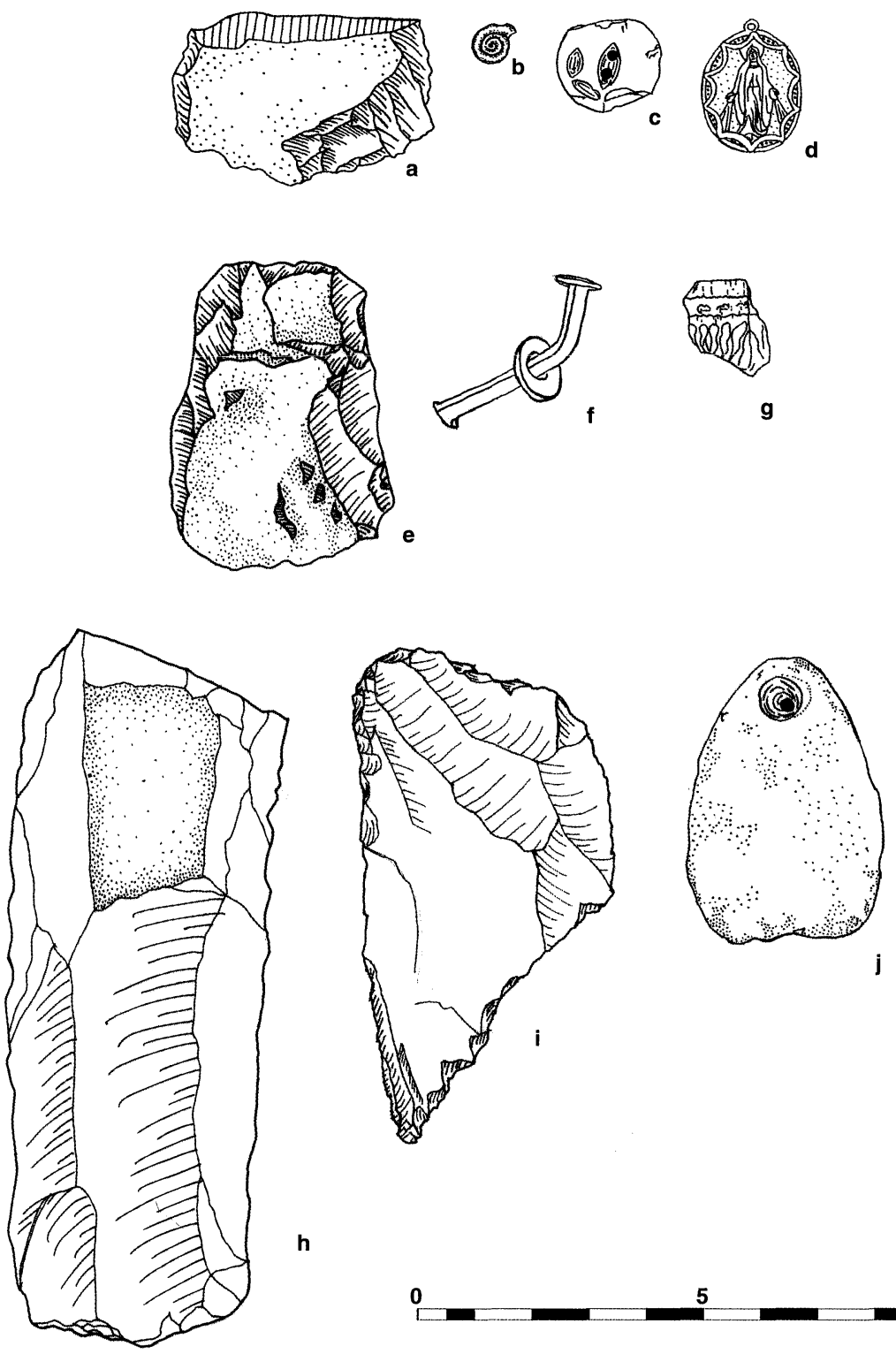

Fig. 6. Selected artifacts from excavations at A'asu. Stratum I: a: highly polished adzed fragment; b: plastic shell-motif bead; c: reworked shell button; d: Catholic devotional medal. Stratum II: e: basalt adze; f: copper boat-building nail with rove; g: nineteenth-century kaolin clay tobacco pipe fragment. Stratum III: h: basalt adze fragment; i: basalt engraver-scraper multi-tool; j: stone net-weight.

\section{DISCUSSION: HUMAN RESPONSES TO CHANGING LANDSCAPES}

Several working hypotheses (not necessarily mutually exclusive) are proposed that may account for the erosion and subsequent increased rates of deposition occurring at $A^{\prime}$ asu: (1) A regional shift in climate triggered a systematic environmental 


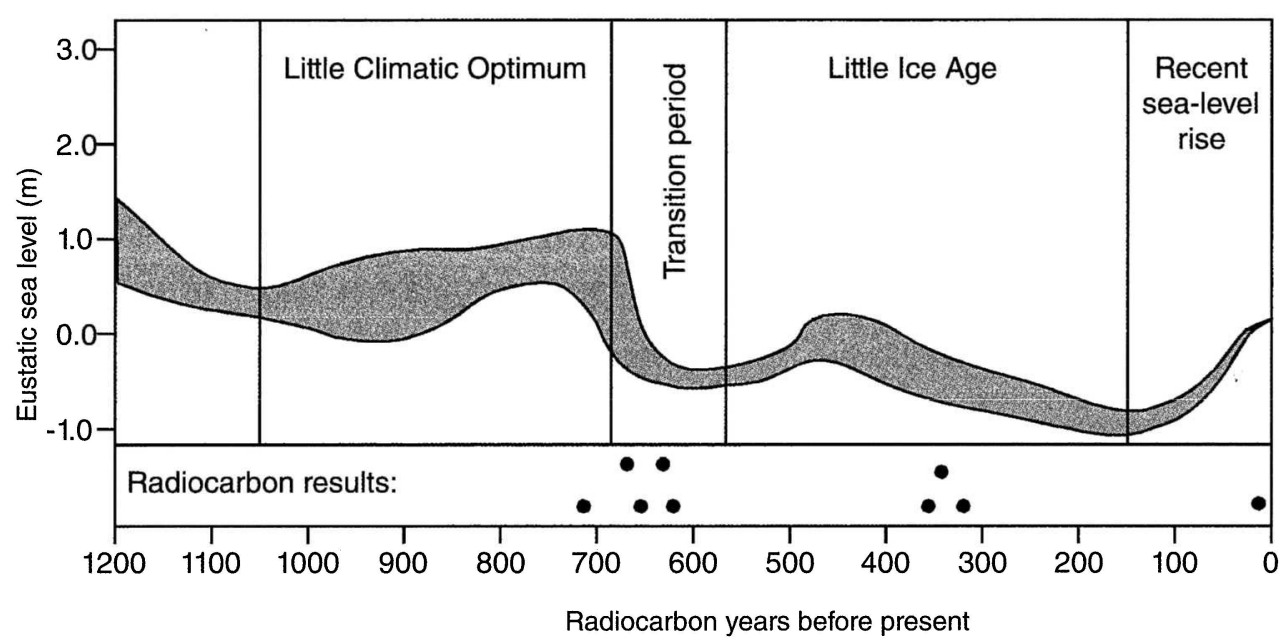

Fig. 7. Sea-level curve (from Nunn 1998) with dates from A'asu shown below. All ages are shown in radiocarbon years (B.P.).

response; (2) a shift in human land use resulted in the environmental changes; or (3) a short-term phenomenon, such as a major storm and landslide, resulted in catastrophic yet localized environmental change.

Nunn (2000) cites evidence scattered throughout the Pacific Basin for dramatic environmental change around 650 B.P. Superimposing the dates from A'asu with the relative sea level curve, it is seen that the five oldest dates cluster in the early to middle transitional period, 670-555 в.P. (Fig. 7). The latest three cluster after 475 в.P. During that interval between the two age clusters, there is substantial erosion and rapid deposition-a very dynamic landscape signature. This could be interpreted as an adjustment in the dynamic equilibrium of the landscape, as it manifests for up to a century after climate change begins.

The results from A'asu do not falsify the notion proposed by Wilson et al. (1979) and elaborated by Nunn (1998) that environmental changes associated with the transition between the Little Climatic Optimum and the Little Ice Age were profound; however, the data do not suggest a solely environmental cause. Rapid sedimentation in the valley is accompanied by abundant charcoal, which may be associated with human land use, especially in moist tropical settings.

According to a surface reconnaissance survey in eastern Tutuila (Clark and Herdrich 1993), regular use of upland ridges for anything other than specialized activities (e.g., basalt quarries and pigeon-snaring mounds) emerged only in the second millennium A.D. This survey identified numerous residential complexes (such as at Lefutu and Old Vatia) that consist of terraces excavated into the mountain ridges to serve as house foundations and cultivation areas (see Fig. 2). Recent work at the three largest known mountain settlements on Tutuila showed that they were initially established within a narrow time frame, approximately A.D. 1270-1310 (Pearl 2004). It is uncertain at this time how much earth was moved in the settlement of these sites, but it is conservative to estimate that thousands of cubic meters were moved in their construction. Some excavated sedi- 
ments were possibly incorporated into the construction of ceremonial mounds, while others may have been discarded down the ridges. Additional work is needed at mountain ridgetop settlements to investigate their construction sequences and relationships to other sites.

This interpretation of A'asu fits well with previous geological and archaeological studies in Samoa that have also revealed rapid sedimentation in the last 1000 years. At To'aga, on nearby Ofu Island, Hunt and Kirch $(1997: 113)$ associate increased sedimentation in the last 1000 years with increased upslope forest clearance, agricultural activity, and subsequent erosion. To'aga, however, produced no dates from that period to sufficiently narrow down the time frame of rapid coastal progradation. At 'Aoa (AS-23-05), a deeply stratified site on the northeastern shore of Tutuila, there is a gap in radiocarbon determinations between $510 \pm 70$ B.P. and $2460 \pm 110$ B.P. (Clark and Michlovic 1996). While Clark and Michlovic do not interpret any major periods of erosion in their stratigraphy, they attribute the late rapid sedimentary cover at the site to increased agricultural activity on the surrounding slopes (156).

A better comparison, even if the chronology is not well understood, comes from Maloata (AS-34-034), a narrow alluvial valley on the northwest coast of Tutuila just $6 \mathrm{~km}$ west of A'asu (see Fig. 1) that was intensively surveyed and excavated by Ayres and Eisler (1987). Like A'asu, Maloata is a deep, narrow alluvial valley that dissects the northwest coast, with similar catchment area and discharge rates (Wong 1996). Its similar geographic position, valley characteristics, and deep alluvial profiles provide an excellent comparison to A'asu.

The deepest stratigraphic profile from Maloata (test pit 1) showed a nearly identical sedimentary pattern to that at A'asu (Ayres and Eisler 1987:60). From the surface to $40 \mathrm{~cm}$, the soil consists of mixed sediments, small river cobbles and coral ('ili'ili), "black soil," and abundant charcoal and shells, probably related to the occupation of an overlying structure. From 40 to $70 \mathrm{~cm}$ the clayey matrix is broken with fine to coarse angular gravels. At $70 \mathrm{~cm}$ there is an abrupt discontinuity, interpreted as a cultural "floor," below which the sedimentary texture is predominately clays, with only occasional cobbles.

These three zones broadly correlate to major strata I, II, and III at A'asu. The abrupt, irregular transition between the coarse colluvial deposition and the underlying fine-grained fluvial deposition is precisely the relationship between strata II and III at A'asu. At Maloata, a single radiocarbon date of $1540 \pm 130$ B.P. (Beta 14709) in the fine-grained layer, however, demonstrates a greater antiquity for the fluvially dominated depositional regime at Maloata than we were able to show at $A$ 'asu.

In addition to the present work, evidence from elsewhere in Tutuila (Ayres and Eisler 1987; Clark and Michlovic 1996), Manu'a (Hunt and Kirch 1997), and 'Upolu (Goodwin and Grossman 2003) indicate that rapid slope-eroded sedimentation in the late Holocene is widespread in the archipelago. Although the overall pattern appears consistent, valleys with different ecological parameters undoubtedly responded in variable ways. Empirically, the A'asu case reveals a strong correlation of climate, sea level, and geomorphic change beginning about A.D. 1300 to 1400 . The comparative example of Maloata is encouraging and, along with the similar examples cited above, seems to preclude the possibility that the observed landscape change is a localized phenomenon. 


\section{CONCLUSIONS AND A HYPOTHESIS ON LAND-USE CHANGES}

IN THE LAST 600 YEARS

A plausible expanded hypothesis for Tutuila is that coastal populations grew during the Little Climatic Optimum, making use of the lowlands and low valley walls for agricultural purposes. However, the increased rainfall, cooler temperatures, lower sea level, increasingly violent weather patterns, and erosion that are linked to the Little Ice Age created a need for alternative land-use strategiesspecifically, intensification of upland landscape use. Abundant charcoal on the valley floor is the direct result of upland erosion coincident with the establishment of mountain residential areas, increasing numbers of ceremonial mounds, and forest clearance for agricultural expansion.

Recent work at the three largest known mountain settlements on Tutuila showed that they were initially established during the transitional period between the Little Climatic Optimum and the Little Ice Age, approximately 660 to 700 B.P. (Pearl 2004). Large settlements such as these rivaled their coastal counterparts in size and came to be prominent population centers until the early to mid-1800s (Davidson 1969). It now seems likely, given the correlation between climate change and expansion into the mountains for settlement purposes, that climate change was an important factor in their initial settlement. Increasing coastal populations may have eventually forced villagers to the mountains for new agricultural opportunities. But climate change created conditions that must have exacerbated food supply problems, possibly resulting in food shortages or at least shortages in the surpluses upon which the matai system depended.

I believe that the establishment of monuments and permanent settlements can be seen as part of an attempt by chiefs to strengthen their claims to mountain resources. If true, mountain settlements would have provided a coastal village with a priority stake in mountain resources, while the coastal villages provided reciprocal access to marine resources. Mountain sites would take on even more importance if competitiveness over resources included an increase in warfare. Many nonresidential sites in the mountains and ridgetops of Samoa have been interpreted as fortifications and refuge sites (Buist 1967; Frost 1978), with Best (1992, 1993) in particular arguing this point. These sites have not been adequately dated, though it is clear that upland use at Tataga Matau, for example-which incorporates residential areas, basalt quarries, a ceremonial "star" mound, and fortifications into its plan-began its intensive use after 600 B.P. (Leach and Witter 1990).

In this article I have presented data that shows high, localized rates of deposition in the narrow alluvial valley at A'asu. Along the valley margins, high rates due to substantial colluvial input exceeded $24 \mathrm{~cm}$ per century, but they must have been higher at times since some of that period is expressed as an erosional vacuity. Similarly, rates on the valley floor were in excess of $15 \mathrm{~cm}$ per century. Landscape erosion occurred between 650 and 350 B.P., which corresponds with the transition to the Little Ice Age from the preceding Little Climatic Optimum. Geomorphic change at A'asu, then, is part of a larger landscape evolution scheme that broadly corresponds to a regional period of increased rainfall, cooler temperatures, lower sea level, and increasingly violent weather patterns.

Effects of these changes are still poorly understood in Samoa, but it is reasonable to expect that a people so closely dependent upon the land and sea must have 
mounted some response. The initial settlement and more widespread use of upland ridgetops seems timed to this period and might be one example of flexible settlement systems in place during the fourteenth century A.D.

Additional research into the late Holocene paleoecology of Samoa is warranted, as are in-depth studies of one or more upland settlements. To better understand how humans responded to changes in landscape and climate during the late Holocene, it will be necessary to continue archaeological investigations, with a key objective to focus on the period of A.D. 1300-1400.

It is impossible to ignore the synchronicity of climate transition, land-use pattern shifts, and geomorphic dynamism seen in the combined geoarchaeological record. Yet it is beyond the resolution of our understanding to pinpoint, at this time, whether rapid landscape evolution follows on the heels of upland migration, or whether that population movement was triggered by landscape instability on the valley floor. Two things are needed to further evaluate this phenomenon: (1) a higher resolution Holocene climate record, perhaps through microbotanical studies and (2) careful studies of the sedimentary record, perhaps through the application of soil micromorphology.

\section{ACKNOWLEDGEMENTS}

Major funding for this research was provided by the Office of the Vice President for Research at Texas A\&M University. Key personnel in the field and lab who assisted in the project include Sandy Loiseau-Vonruff, Phillip Johnson, and Mark Feulner. Artifact illustrations are by Kimberly Hill and Kristine Nicole Ferre of the Texas A\&M University Galveston Archaeology Laboratory. Logistical support was provided by the American Samoa Historic Preservation Office. Peter White, David Herdrich, Robyn Pearson, and six anonymous reviewers provided comments that greatly improved the final version. The author would also like to thank the many volunteers in Texas and Samoa who assisted the project. A special thanks to the people of A'asu and the family of PC Lualemaga E. Faoa, without whom the project would not have been possible.

\section{NOTES}

1. This study was made in conjunction with an archaeological investigation, the goal of which was to provide the prehistoric context for the tragic encounter in 1787 between French explorers and Samoans that resulted in great loss of life and earned this historic site the moniker of "Massacre Bay" (de Langle 1954:188-195; Dunmore 1994 :lxiii, 397-411). The archaeological interpretations of that study are still pending, and this article focuses on the site geomorphology and the implications of rapid landscape evolution.

2. At the request of the village leaders, this burial was only briefly exposed, then covered and left undisturbed.

\section{REFERENCES}

Ayres, William S., and David Eisler

1987 Archaeological survey in western Tutuila: A report on archaeological site survey and excavations. Unpublished report. American Samoa Historic Preservation Office, Tutuila, American Samoa.

Best, Simon B.

1992 Fortifications in Fiji and Samoa: Comparisons and predictions. Archaeology in New Zealand 35(1): 40-44.

1993 At the halls of the mountain kings. Fijian and Samoan fortifications: Comparison and analysis. The Journal of the Polynesian Society 102:385-447. 
Bridgeman, Howard A.

1983 Could climate change have had an influence on the Polynesian migrations? Paleogeography, Paleoclimatology, and Paleoecology $41: 193-206$.

Bronk Ramsey, C.

2001 Development of the radiocarbon calibration program OxCal. Radiocarbon 2A:355-363.

2005 OxCal Version 3.10. Oxford, UK: Oxford Radiocarbon Accelerator Unit.

Buist, A. G.

1967 Field survey in Savai'i, Western Samoa. New Zealand Archaeological Association Newsletter $10(1): 34-52$.

Clark, JefFrey T., and David J. Herdrich

1993 Prehistoric settlement system in eastern Tutuila, American Samoa. The Journal of the Polynesian Society 102:147-185.

Clark, JefFrey T., ANd Michael G. Michlovic

1996 An early settlement in the Polynesian homeland: Excavations at 'Aoa Valley, Tutuila Island, American Samoa. Journal of Field Archaeology $23: 18$.

DAVIDSON, JANET M.

1969 Settlement patterns in Samoa before 1840. The Journal of the Polynesian Society 78:4482.

de Langle, Paul F.

1954 La Tragique Expédition de La Pérouse et Langle. Paris: Hachette.

Dickinson, William R.

2001 Paleoshoreline record of relative Holocene sea levels on Pacific Islands. Earth Science Reviews 55:191-234.

Dickinson, William R., and Roger C. Green

1998 Geoarchaeological context of Holocene subsidence at the Ferry Berth Lapita Site, Mulifanua, Upolu, Samoa. Geoarchaeology: An International Journal 13:239-263.

DunMore, JoHN

1994 The Journal of Jean-François de Galaup de la Pérouse, 1785-1788. 2 vols. London: Hakluyt Society.

Frost, JANET O.

1978 Archaeological Investigations on Tutuila, American Samoa: A Case History. Ph.D. diss. University of Oregon, Eugene.

Goodwin, IAn D., and Eric E. Grossman

2003 Middle to late Holocene coastal evolution along the south coast of Upolu Island, Samoa. Marine Geology 202:1-16.

Grant-Taylor, T. L., AND T. A. RAFTER

1962 New Zealand radiocarbon age measurements. New Zealand Journal of Geology and Geophysics $5: 331-359$.

Hiroa, Te Rangi

1930 Samoan Material Culture. Bernice P. Bishop Museum Bulletin 75. Honolulu: Bishop Museum Press.

Hunt, Terry L., and Patrick V. Kirch

1997 Historical ecology of Ofu Island, in Historical Ecology in the Pacific Islands: Prehistoric Environmental and Landscape Change: 105-203, ed. P. V. Kirch and T. L. Hunt. New Haven: Yale University Press.

Leach, Helen M., and Dan C. Witter

1990 Further investigations at the Tataga-matau site, American Samoa. New Zealand Journal of Archaeology 12:51-83.

Milet-Mureau, Louis A.

1797 Voyage de la Pérouse Autour du Monde, Publié Conformément au Décret du 22 Avril 1791. 4 vols. Paris: Imprimerie de la République.

Mitrovica, J. X., And W. R. Peltier

1991 On postglacial geoid subsidence over the equatorial oceans. Journal of Geophysical Research 96:20,053-20,071. 
Nunn, Patrick D.

1995 Holocene sea-level changes in the South and west Pacific. Journal of Coastal Research $17: 311-319$.

1998 Sea-level changes over the last 1000 years in the Pacific. Journal of Coastal Research 14:2330.

2000 Environmental catastrophe in the Pacific Islands around A.D. 1300. Geoarchaeology: An International Journal $15: 715-740$.

Pearl, Frederic B.

2004 The chronology of mountain settlements on Tutuila, American Samoa. The Journal of the Polynesian Society 113:331-348.

Reimer, Paula J., Mike G. L. Baillie, Edward Bard, Alex Bayliss, J. Warren Beck, Chanda J. H. Bertrand, Paul G. Blackwell, Caitlin E. Buck, George S. Burr, Kirsten B. Cutler, Paul E. Damon, R. Lawrence Edwards, Richard G. Fairbanks, Michael Friedrich, Thomas P. Guilderson, Allan G. Hogg, Konrad A. Hughen, Bernd Kromer, Gerry McCormac, Sturt Manning, Christopher Bronk Ramsey, Ron W. Reimer, Sabine Remmele, John R. Southton, Minze Stuiver, Sahra Talamo, F. W. Taylor, Johannes van der Plicht, and Constanze E. WEYHENMEYER

2004 Radiocarbon calibration from 0-26 cal kyr B.P. Radiocarbon 46(3) :1029-1058.

RODDA, P.

1988 Visit to Western Samoa with the HIPAC team, in Sea-Level Changes and Tectonics in the Middle Pacific: Report of the HIPAC Project in 1986 and 1987: 85-90, ed. N. Yonekura. Tokyo: University of Tokyo Press.

StafF, Soll Survey

2003 Keys to Soil Taxonomy, 9th. Washington, DC: U.S. Department of Agriculture, Natural Resources Conservation Service.

Stearns, Harold T.

1944 Geology of the Samoan Islands. Bulletin of the Geological Society of America 55:1279-1332.

Stuiver, Minze, and Gordon W. Pearson

1993 High-precision calibration of the radiocarbon time scale, A.D. 1950-500 B.C. and 25006000 B.C. Radiocarbon 35(1): 1-23.

Sugimora, A., Y. Maeda, Y. Matsushima, and P. Rodda

1988 Further report on sea-level investigations in Western Samoa, in Sea-Level Changes and Tectonics in the Middle Pacific: Report of the HIPAC Project in 1986 and 1987: 77-84, ed. N. Yonekura. Tokyo: University of Tokyo Press.

Wilson, A. T., C. H. Hendy, and C. P. Reynolds

1979 Short-term climate change and New Zealand temperatures during the last millennium. Nature 279:315-317.

Wong, Michael F.

1996 Analysis of Streamflow Characteristics for Streams on the Island of Tutuila, American Samoa. Water Resources Investigations Report 95-4185. Honolulu: U.S. Geological Survey.

\section{ABSTRACT}

Archaeological excavations at the coast of A'asu, in Tutuila Island of American Samoa, exposed a depositional sequence spanning the past circa 700 years. With the period represented, sedimentation rates exceeded $10.15 \mathrm{~cm}$ per century in the valley floor and $16.34 \mathrm{~cm}$ per century along the valley margin. The occupational history may correlate with changes in climate, sea level, and coastal geomorphology. Although the evidence accords with the expected responses to the Little Climatic Optimum (circa 1050 to 690 B.P.) and Little Ice Age (circa 575 to 150 B.P.), the most plausible explanation for the A'asu case is that environmental change accompanied expansion of upland land use. Based on evidence here and elsewhere in Tutuila, it is proposed that the establishment of fortifications, monuments and permanent settlements in the uplands was part of a broader pattern of land-use expansion beginning in the fourteenth century A.D. KeYwords: American Samoa, Polynesia, landscape evolution, prehistoric human impacts, geochronology. 